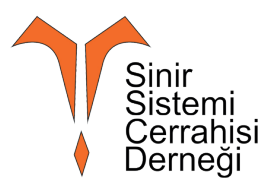

\title{
Spinal intradural endodermal cyst
}

\section{Spinal intradural endodermal kist}

\author{
Esin Yiğitbaşı ${ }^{1 \oplus}$, Nuket Özkavruk Eliyatkın ${ }^{2 \oplus}$, Varol Aydın ${ }^{3 \oplus}$, \\ Yelda Özsunar Dayanır ${ }^{4}$ \\ ${ }^{1}$ Kilis Devlet Hastanesi, Kilis. \\ ${ }^{2}$ İzmir Katip Çelebi Üniversitesi Tıp Fakültesi, Patoloji Anabilim Dalı, İzmir. \\ ${ }^{3}$ Adnan Menderes Üniversitesi Tıp Fakültesi, Nöroşirurji Anabilim Dalı, Aydın. \\ ${ }^{4}$ Adnan Menderes Üniversitesi Tıp Fakültesi, Radyoloji Anabilim Dalı, Aydın.
}

Atıf/Cite as: Yiğitbaşı E, Özkavruk Eliyatkın N, Aydın V, Özsunar Dayanır Y. Spinal intradural endodermal cyst. J Nervous Sys Surgery 2021;7(2):78-82.

Geliş tarihi/Received: 11.04.2021 Kabul tarihi/Accepted: 18.08.2021 Yayın tarihi/Publication date: 30.10 .2021

\begin{abstract}
Purpose: Epithelial cysts of the central nervous system, according to the type of cell origin; neuroepithelial or endodermal type. Endodermal cysts are rare forms of benign tumors. In this presentation, we present a 35-yearold male patient with typical histopathologic features and due to the presence of this rare lesion. We aimed to present this rare case and emphasize the importance of cystic epithelial cell differences.

Methods: Neurenteric cysts, cyst lining epithelium of cell types were analyzed using immunohistochemical diagnostic methods.

Results: The importance of the cell type in the endodermal cyst is also emphasized and the frequency of recurrence in cysts that have goblet-columnar epithelial component. This epithelium is increasing the risk of recurrences. However, the other cause of recurrence is also incomplete excision. Therefore, the complete excision of ECs is important, not only for avoiding recurrence but also for differentiating cell types for ECs and predicting recurrence risk.

Conclusions: The precise pathologic diagnosis of cell type determines the risk of recurrence. Neurosurgeons should exert their best efforts to achieve complete excision of the cysts.
\end{abstract}

Keywords: Endodermal cysts, Immunohistochemical, Pathogenesis

\section{ÖZ}

Amaç: Endodermal kistler benign tümörlerin nadir görülen formlarıdır. Bu sunumda, tipik histopatolojik özellikleriyle intradural yerleşimli endodermal kist olgusu olan 35 yaşında bir erkek hastayı sunuyoruz. Bu nadir olgu sunumunda kiste ait epitel hücre farklılıklarının önemini vurgulamayı amaçladık.

Yöntemler: Nöroenterik kistler ve kist döşeyici epiteli hücre tipleri immünohistokimyasal tanı yöntemleri kullanılarak analiz edildi.

Bulgular: Endodermal kistte hücre tipinin önemi vurgulanmış olup goblet-kolumnar epitel bileşeni olan kistlerde nüks sıklığı arttığı bulunmuştur. Bununla birlikte, bir diğer nüks nedeni de tamamlanmamış cerrahi eksizyondur. $\mathrm{Bu}$ nedenle, endodermal kistlerin tamamen eksize edilmesi, sadece nüksten kaçınmak için değil, aynı zamanda kist epiteli hücre tiplerini ayırt etmek ve nüks riskini öngörmek için de önemlidir.

Sonuç: Hücre tipinin kesin patolojik tanısı tekrarlama riskini belirler. Beyin cerrahları, kistlerin tam olarak çıkarılmasını sağlamak için ellerinden geleni yapmalıdır.

Anahtar Kelimeler: Endodermal kistler, immünhistokimya, patogenez \footnotetext{
esinyigitbasi@gmail.com / 0000-0003-2706-3143

ORCID:

(C) Telif hakk1 Sinir Sistemi Cerrahisi Dergisi.

Bu dergide yayınlanan bütün makaleler Creative Commons 4.0 Uluslararası Lisansı (CC-BY) ile lisanslanmıştır.

(C) Copyright Journal of Nervous System Surgery.

Licenced by Creative Commons Attribution 4.0 International (CC BY).
}

Sorumlu yazar/Corresponding author: Esin Yiğitbaşı, Adnan Menderes Üniversitesi Tıp Fakültesi, Patoloji Anabilim Dalı, Aydın.

N. Özkavruk Eliyatkın 0000-0002-7784-5699, V. Aydın 0000-0001-7447-4549, Y. Özsunar Dayanır 0000-0003-2642-5464 


\section{INTRODUCTION}

Development cysts of central nervous system can be divided into based on their cell of origin and the nature of the cyst lining; endodermal, ectodermal and neuroectodermal cysts. Endodermal cysts of the central nervous system are also known as neuroenteric or enterogenic cysts. These cysts are endodermal origin and among the rare congenital lesions. Typically, they ocur on the subdural surface of the spinal cord ${ }^{(1)}$. Spinally positioned endodermal cysts are histologically covered with mucin-producing columnar cells supported by connective tissue. Rarely, adenocarcinomatous transformation of such cysts can be occurred ${ }^{(2)}$. For this reason, the total surgical excision of the lesion is recommended.

In this presentation, we present a 35-year-old male patient with typical histopathologic features and due to the presence of this rare lesion.

\section{CASE REPORT}

A 35-year-old man presented with complaints of waist and right leg pain for about a week. Physical examination showed limitation of waist movement and paravertebral spasm. Neurological examination showed positive leg lift test on the right side at 45-50 degrees, 3/5 muscle loss in the dorsal flexion of the right foot and hypoesthesia in the right L4-S1 dermatomes. On the Lomber MRI examination, L5 sacralization was determined and a mass showing a T1A hyperintense post contrast sera opacification mass, extending from the upper end plate of the T10 vertebra to the upper end plate of the T11 vertebra, and compressing towards the extra axial intradural spinal coronary artery, at $32 \times 11 \times 10$ $\mathrm{mm}$ in the widest area, was observed (Figure 1). Surgery and excition of mass with preoperatively diagnosis of menengioma was planned. In the operation, Th10 and Th11 total laminectomy were performed, but no mass appearance was detected in the extradural area. When opened vertically along the dura midline, the lesion was found to be completely cystic at the intraduralextramedullary distance. Surgical microscope aspiration was performed using an injector from the intra-cyst fluid, and then the cyst wall was opened, no solid mass was observed within the cyst walls and cyst. Surgical intervention was terminated by excisional biopsy of the cyst wall.

The material sent for post-operative evaluation consists of a biopsy material in a dark white color with a diameter of $0,4 \mathrm{~cm}$. All material was fixed in $10 \%$ formalin, dehydrated, and embedded in paraffin for histological test. In the sections, thin fibrous membranous cyst wall with low columnar-ciliary epithelium was observed. The cystic epithelium is locally ciliated and it was rich in goblet cells in the focal areas. Most areas of wall structure was thin and membraneus, in some areas it was thicker and fibrotic. Congested vessel structures were also

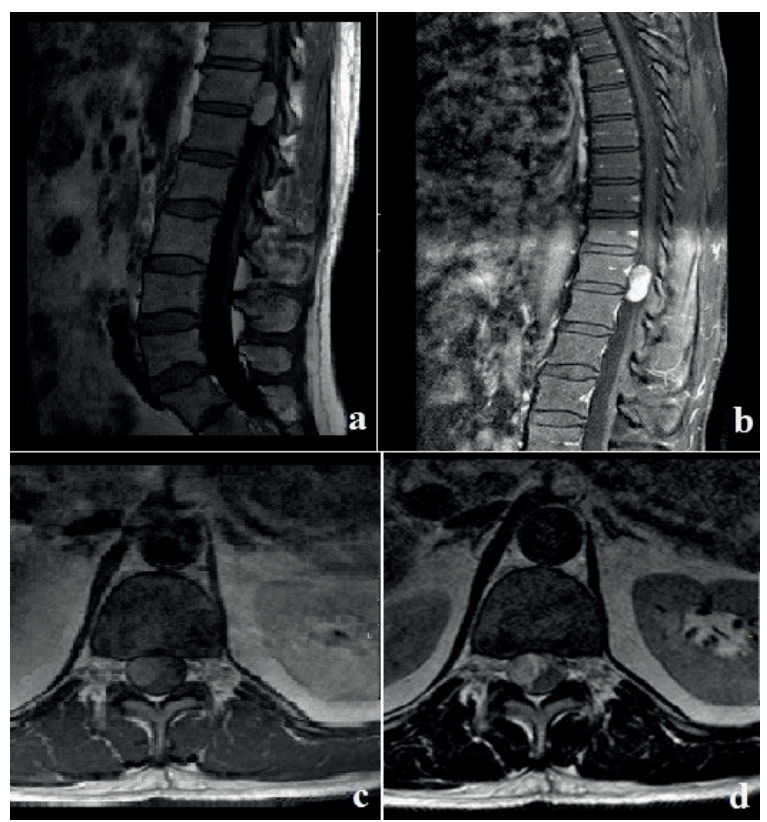

Figure 1. Magnetic resonance imaging of case. An intradural-extramedullary cystic lesion was noted at the spinal canal of the T11 to T12 level. (a: T1 sagittal precontrast, b: $\mathrm{T} 1$ sagittal postconstrast, c: $\mathrm{T} 1$ axial precontrast, $\mathrm{d}$ : $\mathrm{T} 2$ axial) 
observed (Figure 2). The presence of histiocytes containing a brown pigment in a focal area was observed. Positive staining with Prussian blue applied by histochemical method was observed. Pancytokeratin(diffuse-strong), cytokeratin 7 and EMA staining in cystic epithelium were observed. IHC stains reported negative for glial fibrillary acidic protein (GFAP), cytokeratin 20 (CK20), caudal-type homeobox 2 (CDX2), mucin 2 (MUC2), mucin 5 (MUC5), thyroid transcription factor-1 (TTF-1).

A final diagnosis was "Endodermal Cysts" based on histological and immunohistochemical findings.

\section{DISCUSSION}

Epithelial cysts of the central nervous system, according to the type of cell origin; neuroepithelial or endodermal type. The real neuroepithelial cysts of the neuroectodermal origin are the choroid plexus cysts and the ependymal cysts. The neuroepithelial cysts are believed to arise from the heterotopic rests of primitive ependyma, whereas the ECs are believed to arise from the remnants of the transient neurenteric canal during notochordal development ${ }^{(3,4)}$.

Endodermal cysts are rare forms of benign tumors that comprise about $0.01 \%$ of all central nervous system tumors ${ }^{(5)}$ and they are characteristically located in the subarachnoid space anterior to the spinal cord and most commonly in the cervical region. Generally accepted opinion about the development of endodermal cysts isincomplete separation of the endodermal foregut structure and ectoderm-derived spinal canal during early embryogenic life ${ }^{(3)}$. Endodermal cysts are divided into three different forms by some

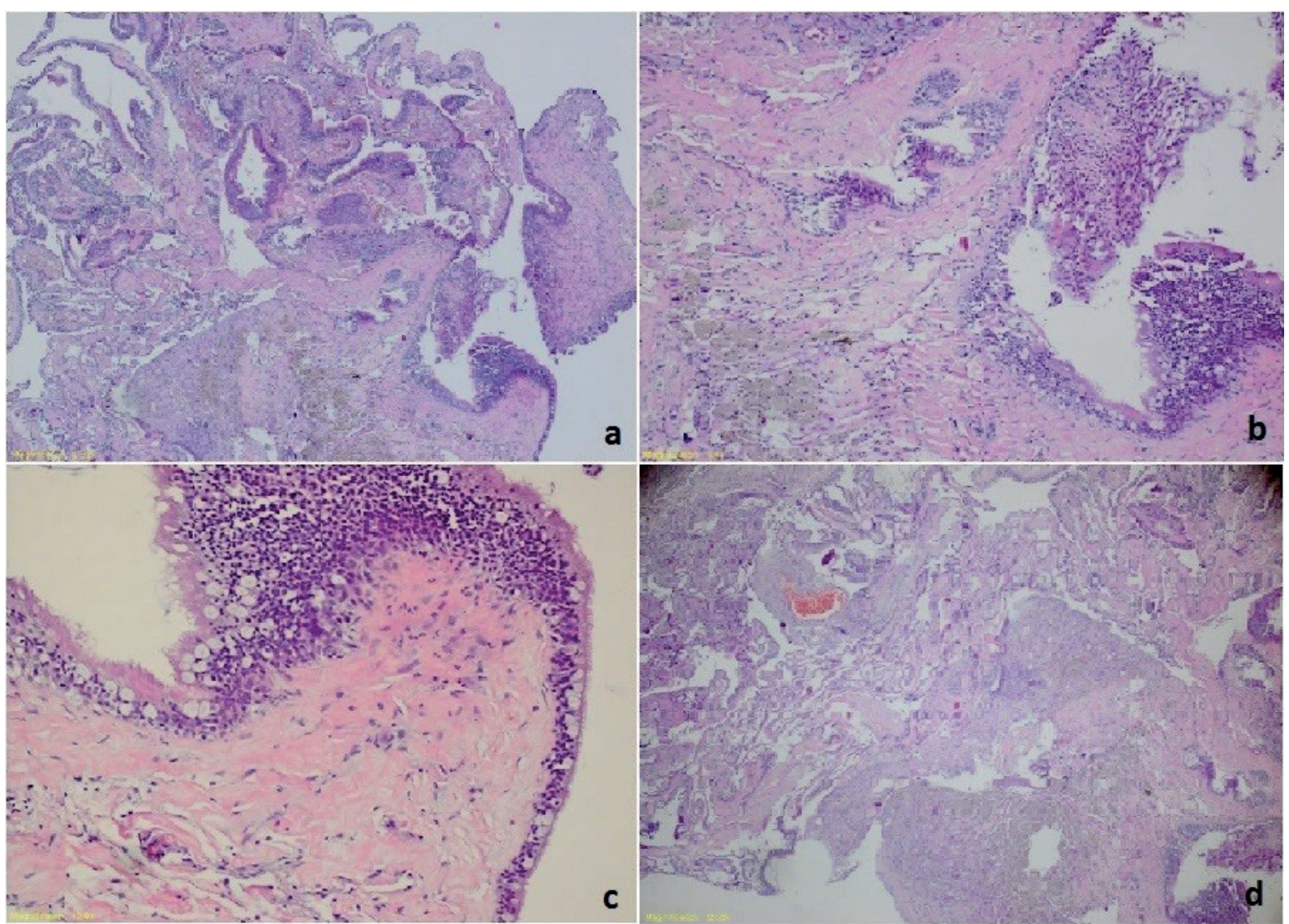

Figure 2. Photomicrographs showed a combination of 2 cell types: pseudostratified-ciliated epithelium and columnar epithelium with goblet cells (a: H\&E x4, b: H\&E x10, c: H\&E x20, d: H\&E x4) 
authors ${ }^{(6)}$. The most simple primitive form, type A; are thin walled, with a layer of stratified or a pseudostratified cuboidal or columnar epithelium on a basement membrane. Two more complex forms are as follows; Type B and type C. Both are the more rare type. Type $\mathrm{B}$ also has additional mesodermal elements such as smooth muscle tissue and fat tissue. Type $\mathrm{C}$ has ependymal or glial tissue. We think that our case is in the type A form, because it is in the form of a cyst with a thin fibrous wall with epithelial remmants including ciliated and goblet cells in some places.

Studies have shown that the epithelium of the cyst structure generally has three different cell types: (7) pseudostratified-ciliated cells, simple columnar epitheliumwith goblet cells (gobletcolumnar), and simple cuboidalcells. It has mostly been reported as 2 types, pseudostratified-ciliated epithelium and goblet-columnar epithelium. In previous reports, it has have reported that such cysts only in a third of cases are epithelialized in a mixed-type epithelium which combine both cell types ${ }^{(6-8)}$ reported that the mixed epithelium is the most common type. This difference may result from incomplete excision of such cysts or incomplete histologic examination of specimens. Therefore, the complete excision of cysts is important, not only for avoiding recurrence but also for differentiating cell types for ECs and predicting recurrence risk. We studied all of the cystic material. All of the cell types were present in the cross sections of our present.

The importance of the cell type in the endodermal cyst is also emphasized and the frequency of recurrence in cysts that have gobletcolumnar epithelial component. Therefore, immunohistochemical stains have been applied in the literature to determine the origin of such cells ${ }^{(7)}$. In our case, epithelial lining epithelium cytokeratin and EMA positivity suggested that the epithelium was of endodermal origin. We excluded ectoderm origin with GFAP, NSE and vimentin negativity. We also demonstrated the presence of secretory granules of goblet cells by PAS specific histochemical staining which supports endodermal origin. CK20, CDX2, and MUC2 negativity suggested that goblet-columnar cells originated primarily from the stomach (not the intestine). CK7 and MUC5A markers are expressed in both respiratory tissue and the stomach, but we showed only CK7 positivity, not MUC5 in our specimens. TTF-1, the respiratory tract marker, was also applied and negative. We excluded respiratory tract origin with these immunostaining results (positive for CK7, negative for TTF-1). Chen and colleagues found only 4 cases positive for MUC5A in endodermal cyst studies involving 10 cases ${ }^{(7)}$.

In our case, the cystic epithelium was of the goblet-columnar cell type epithelium. Our event has been followed for 26 months and there is no recurrence. It has been reported in the literature that such epithelium is increasing the risk of recurrences. However, the other cause of recurrence is also incomplete excision. Therefore, the complete excision of ECs is important, not only for avoiding recurrence but also for differentiating cell types for ECs and predicting recurrence risk.

In our case, surgically, it was stated as observer of operation that the entire cyst was excised and no lesions were found with CT.

These lesions are most commonly benign. But, rare instances of both de novo malignancy and malignant transformation of EC in the setting of recurrence have also been reported. Malignant transformation of the EC wall into an adenocarcinoma appears to have been the cause in these patients. 


\section{CONCLUSIONS}

-ECs are located in the group of neuroepithelial cysts and different nomenclature is used for these cysts. We think that such cysts were derived from migrated endodermal cells rather than a component of the neurenteric canal. There is a wide range of needs to be made about this subject.

-Neurosurgeons should exert their best efforts to achieve complete excision of the cysts.

-Neuropathologist should examine histologic evaluation of whole specimen to be able to recognize cellular diversity. Because, the precise pathologic diagnosis of cell type determines the risk of recurrence.

Conflict of interest: There is no conflict of interest in our study.

Funding: No financial support was received in our study.

\section{REFERENCES}

1. Arai, Y., et al., Spinal neurenteric Cyst: Report of Two Cases and Review of Forth-One Cases Reported in Japan. Spine, 1992. 17(11): p. 1421-1423. https://doi. org/10.1097/00007632-199211000-00027

2. Sahara, Y., et al., Recurrence of a neurenteric cyst with malignant transformation in the foramen magnum after total resection: case report. Journal of neurosurgery, 2001. 95(2): p. 341-345. https://doi.org/10.3171/ jns.2001.95.2.0341

3. Hasegawa, M., et al., Neuroepithelial cyst of the fourth ventricle. Child's Nervous System, 2015. 31(1): p. 155159. https://doi.org/10.1007/s00381-014-2478-4

4. Cheng, JS., et al., Lateral supratentorial endodermal cyst: case report and review of literature. Neurosurgery, 2002. 51(2): p. 493-499. https://doi.org/10.1097/00006123200208000-00035

5. Chang, IC. Thoracic neurenteric cyst in a middle aged adult presenting with Brown-Sequard syndrome. Spine, 2003. 28(24): p. E515-E518. https://doi.org/10.1097/01. BRS.0000099391.09971.77

6. Mittal, S., et al., Supratentorial neurenteric cysts-a fascinating entity of uncertain embryopathogenesis. Clinical neurology and neurosurgery, 2010. 112(2): p. 89-97. https://doi.org/10.1016/j.clineuro.2009.11.001

7. Chen, CT., et al., Neurenteric Cyst or Neuroendodermal Cyst? Immunohistochemical Study and Pathogenesis. World Neurosurgery, 2016. 96: p. 85-90. https://doi. org/10.1016/j.wneu.2016.08.089

8. Preece, M., et al., Intracranial neurenteric cysts: imaging and pathology spectrum. American journal of neuroradiology, 2006. 27(6): p. 1211-1216. 